\title{
$\mathrm{CO}_{2}$ 지하저장과 연계한 원유회수증진 기술 김형목*, 배위섭
}

\section{Enhanced Oil Recovery (EOR) Technology Coupled with Underground Carbon Dioxide Sequestration}

\author{
Hyung-Mok Kim*, Wi-Sup Bae
}

\begin{abstract}
Enhanced oil recovery (EOR) technology coupled with underground carbon dioxide sequestration is introduced. $\mathrm{CO}_{2}$ can be injected into an oil reservoir in order to enhance oil production rate and $\mathrm{CO}_{2} \mathrm{EOR}$ can be turned into CCS in a long term sense. Coupling $\mathrm{CO}_{2}$ EOR with CCS may secure a large scale and consistent $\mathrm{CO}_{2}$ source for EOR, and the $\mathrm{CO}_{2}$ EOR can bring an additional economic benefit for CCS, since the benefit from enhanced oil production by $\mathrm{CO}_{2}$ EOR will compensate costs for CCS implementation. In this paper, we introduced the characteristics of $\mathrm{CO}_{2}$ EOR technology and its market prospect, and reviewed the Weyburn $\mathrm{CO}_{2}$ EOR project which is the first large-scale $\mathrm{CO}_{2}$ EOR case utilizing an anthropogenic $\mathrm{CO}_{2}$ source. We also introduced geotechnical elements for a successful and economical implementation of $\mathrm{CO}_{2}$ EOR with CCS and they were a miscroseismic monitoring during and after injection of $\mathrm{CO}_{2}$, and determination of minimum miscible pressure (MMP) and maximum injection pressure (MIP) of $\mathrm{CO}_{2}$.
\end{abstract}

Key words Carbon dioxide underground sequestration, Enhanced Oil Recovery (EOR), Minimum Miscible Pressure (MMP), Maximum Injection Presssure (MIP), miscroseismic monitoring

초 록 본 고에서는 $\mathrm{CO}_{2}$ 지중저장과 연계한 원유회수증진 기술을 소개하였다. 원유회수증진을 목적으로 $\mathrm{CO}_{2}$ 를 저류층 내에 주입하는 $\mathrm{CO}_{2} \mathrm{EOR}$ 기술은 장기적인 관점에서 $\mathrm{CO}_{2}$ 를 지하 심부 암반에 저장하는 $\mathrm{CCS}$ 기술로 전환할 수 있다. $\mathrm{CCS}$ 와 연계한 $\mathrm{CO}_{2} \mathrm{EOR}$ 기술은 $\mathrm{EOR}$ 에 필요한 대규모 $\mathrm{CO}_{2}$ 공급원을 확보할 수 있는 장점이 있으며 원유 회수율 증진에 따른 편익 발생으로 $\mathrm{CCS}$ 를 위한 일련의 프로세스 중, 특히 포집 분야에 경제성을 부가할 수 있는 장점이 있다. 이러한 $\mathrm{CCS}$ 와 연계한 $\mathrm{CO}_{2} \mathrm{EOR}$ 기술의 특징 및 시장 전망을 살펴보고 국외의 대표사례로 Weyburn $\mathrm{CO}_{2} \mathrm{EOR}$ 프로젝트를 소개하였다. 또한, 안정적이고 경제적인 $\mathrm{CO}_{2} \mathrm{EOR}$ 실시에 필요한 제반 기술 요소를 분석하고 $\mathrm{CO}_{2}$ 주입중 및 주입후 장기운영과정에서의 미소진동 계측, $\mathrm{CO}_{2}$ 의 최소혼화압력 및 최대주입압력의 사전설계 등의 암반공학적 쟁점들을 소개하였다.

핵심어 $\mathrm{CO}_{2}$ 지하저장, 원유회수증진, 최소혼화압력, 최대주입압력, 미소지진계측

\section{1. 서 론}

최근 유가 급등으로 인해 기존 저류층 내 잔존 석유 자원

Received: Jan. 7, 2013

Revised: Feb. 20, 2013

Accepted: Feb. 20, 2013

*Corresponding Author: Hyung-Mok Kim

Tel) +82234084387, Fax) +82234084344

E-Mail)hmkim@sejong.ac.kr

Energy \& Mineral Resources Engineering, Sejong University, Seoul 143-747 Korea
의 회수율을 증진시키기 위한 원유회수증진법(Enhanced Oil Recovery, EOR)에 대한 관심이 증가하고 있다. 일 반적으로 원유 생산은 1차, 2차 및 3 차 생산 과정을 거 치게 된다. 1차 생산(primary production)은 저류층 내 유체 압력에 의해서 자연 분출되는 원유를 생산하는 과 정으로 계속적인 생산은 저류층의 압력 손실을 수반하 여 점진적인 생산량 감소를 가져오게 된다. 1 차 생산에 의한 원유 생산량은 초기 원유 매장량(Original Oil In Place, OOIP)의 약 $10-20 \%$ 에 불과한 것으로 알려져 있 다. 2 차 생산(secondary production)은 1 차 생산 과정에 
서의 저류층 내 압력 저하로 자연적인 생산이 불가능한 시 점에 물(혹은 가스)을 저류층에 인위적으로 주입하여 저류 층 내 원유를 밀어내어 생산하는 과정(water flooding)을 말한다. 이러한 2차 생산에 의한 원유 회수량은 OOIP 의 약 $20-40 \%$ 에 해당하는 것으로 알려져 있다. EOR 공법은 마지막 3 차 생산(tertiary production)에 해당하 는 과정으로 저류층 내 잔류 오일의 포화도 혹은 점성 도를 저감시키거나 오일과 물 사이의 계면장력을 감소 시켜 유동성을 증가시킴으로써 잔존 원유의 생산량을 증대시키는 기술이다. EOR에 의한 원유 생산량은 OOIP 의 약 $40-50 \%$ 를 차지하는 것으로 알려져 있다. Fig. 1 은 원유 생산과정에서 각 생산 단계에 의한 생산량 변 화의 일반적 추이를 나타낸 것이다.

3 차 원유 생산과정에 해당하는 $\mathrm{EOR}$ 공법은 크게 3 가지로 세분할 수 있다(Table 1). Gas EOR 공법은 $\mathrm{CO}_{2}$ 및 질소 $\left(\mathrm{N}_{2}\right)$ 가스를 저류층에 주입함으로써 원유와의 혼 화(miscible)/비혼화(immiscible) 과정을 통해 유체 점 성도를 저감시켜 생산량을 증대하는 기술이다. 화학적 $\mathrm{EOR}$ 은 폴리머 및 계면활성제 등을 활용하여 잔류 석유의 상대적인 유동도를 조절하는 기술이다. 열적 $\mathrm{EOR}$ 은 주로 중질유 등과 같은 점성이 높은 저류층에 증기(steam) 혹 은 열수(hot water)를 주입하여 점성도를 낮추어 생산성 을 향상시키는 기술이다. 이외에도 미생물(Mibrobial)을 사용하여 잔류 원유의 표면장력을 감소시키는 친환경

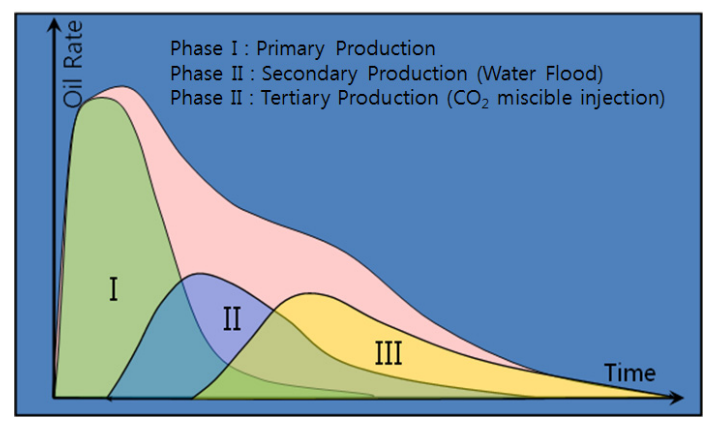

Fig. 1. Oil production rate of three different production phases (reproduced from http://www.edf.org/sites/ default/files/10254_Bradley.pdf, 2013.02)

Table 1. Types and options for EOR

\begin{tabular}{|c|c|c|c|}
\hline Gas & Chemical & Thermal & Others \\
\hline $\begin{array}{c}\mathrm{CO}_{2} \\
\text { Hydrocarbon } \\
\text { Nitrogen Flue } \\
\text { gas Air }\end{array}$ & $\begin{array}{l}\text { Polymer } \\
\text { Surfactant } \\
\text { (foam) }\end{array}$ & $\begin{array}{l}\text { Steam } \\
\text { Combustion } \\
\text { (in situ) } \\
\text { Hot water }\end{array}$ & Microbial \\
\hline
\end{tabular}

적인 방법이 제안되어왔으나 석유 생산량 증대효과는 크지 않은 것으로 알려져 있다. Fig. 2은 저류층 심도 및 점성도에 따른 $\mathrm{EOR}$ 공법의 적용 가능성을 나타낸 것이다.

이들 $\mathrm{EOR}$ 공법 중에서도 $\mathrm{CO}_{2} \mathrm{EOR}$ 공법은 $\mathrm{CO}_{2}$ 를 일정 압력 이상으로 주입하여 원유와 혼화/용해시킴으 로써 원유의 점성도를 감소시켜 회수율을 증진시키는 방식이다. $\mathrm{CO}_{2} \mathrm{EOR}$ 은 이미 수십 년간 활용되어 온 기 술로 2010 년 기준 총 124 개의 $\mathrm{CO}_{2} \mathrm{EOR}$ 프로젝트가 전세계에서 진행중으로 $\mathrm{EOR}$ 에 의한 원유 회수량의 약 $19 \%$ 에 해당하는 것으로 알려져 있다. 대부분의 $\mathrm{CO}_{2} \mathrm{EOR}$ 프로젝트는 미국(114개)과 캐나다(6개)에 집중되어 있 으며 미국의 경우, 총 석유 생산량의 $13 \%$ 를 $\mathrm{EOR}$ 공법 으로 생산하고 있고 이 중 $\mathrm{CO}_{2} \mathrm{EOR}$ 방식에 의한 생산 량이 약 $37 \%$ 를 차지하고 있다(Godec, 2011).

한편, $\mathrm{CO}_{2} \mathrm{EOR}$ 공법을 통한 원유 생산 확대에 있어 가장 큰 걸림돌은 $\mathrm{CO}_{2}$ 의 공급량이 충분치 못하다는 점 을 들 수 있다. NETL(2010)에 의하면 500-1500 sm3 (sm3: standard cubic meter)의 원유를 생산하는데 필 요한 $\mathrm{CO}_{2}$ 양은 1 3 $\mathrm{CO}_{2}$-tonnes 인 것으로 알려져 있다. 또한, $\mathrm{CO}_{2} \mathrm{EOR}$ 공법의 성공적인 실시를 위해서는 주 입개시 후 $10 \sim 30$ 년간 $\mathrm{CO}_{2}$ 가 지속적으로 공급되어야 한다. 지금까지는 천연가스 생산과정에서 회수되는 자 연발생적 $\mathrm{CO}_{2}$ 를 이용하여 $\mathrm{CO}_{2} \mathrm{EOR}$ 프로젝트를 실시 해 왔으나, 최근 온실가스 저감대책으로서의 $\mathrm{CCS}\left(\mathrm{CO}_{2}\right.$ 포집 및 저장, Carbon Capture and Storage) 기술에 대 한 비약적인 관심과 기술 발전으로 인해 대용량 $\mathrm{CO}_{2}$ 의

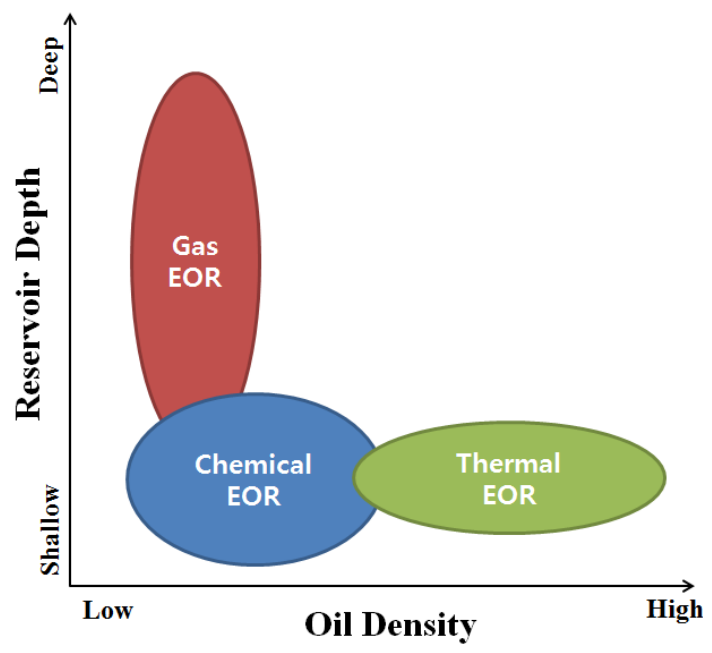

Fig. 2. Types of EOR according to reservoir depth and oil density (reproduced from http://know.ketep.re..kr, 2013.02) 
포집이 가능하게 되었고, $\mathrm{CCS}$ 와 $\mathrm{CO}_{2} \mathrm{EOR}$ 을 연계하여 $\mathrm{CO}_{2}$ 주입을 통해 원유 회수율을 증진시킴과 동시에 $\mathrm{CO}_{2}$ 를 저장함으로써 $\mathrm{CCS}$ 에 소요되는 막대한 비용을 경감시키고 $\mathrm{CCS}$ 의 경제성을 향상시키는 방안이 제시 되고 있다.

본 고에서는 $\mathrm{CO}_{2}$ 를 지하 암반층에 대용량으로 저장하 기 위한 $\mathrm{CCS}$ 기술과 원유 생산 증진을 위한 $\mathrm{CO}_{2} \mathrm{EOR}$ 공법을 연계한 CCS-EOR 기술 동향 및 특징을 살펴보 고자 한다. 또한, $\mathrm{CCS}$ 와 연계한 $\mathrm{CO}_{2} \mathrm{EOR}$ 프로젝트의 대표 사례인 캐나다 Weyburn 프로젝트 사례를 분석함 으로써 이들 프로젝트의 성공적 수행을 위한 관련 기술 개발 요소를 도출하였다. $\mathrm{CCS}$ 와 연계한 $\mathrm{CO}_{2} \mathrm{EOR}$ 기 술 개발 자립화는 인도네시아 등과 같은 석유기술 개발 도상국 시장에의 진출, 온실가스 저감을 통한 기후변화 협약에의 적극적 동참, 신규 상업적 부가가치 창출 등 의 기대효과를 가져올 수 있을 것으로 기대된다.

\section{2. $\mathrm{CO}_{2} \mathrm{EOR}$ 기술 개요 및 특징}

$\mathrm{CO}_{2} \mathrm{EOR}$ 기술은 1 차 및 2 차 생산 과정을 통해 저류 층 내 압력이 일정수준 이하로 떨어진 유전을 대상으로 $\mathrm{CO}_{2}$ 를 고압으로 주입함으로써 저류층 내 잔존 석유 자 원의 회수율을 증진시키는 원유회수증진법(Enhanced Oil Recovery, $\mathrm{EOR}$ )의 일종이다. $\mathrm{CO}_{2} \mathrm{EOR}$ 은 주입된 $\mathrm{CO}_{2}$ 와 저류층 내 잔존 원유의 혼화여부에 따라 두 가지로 분류할 수 있다(Lee et al., 2012).

혼화(miscible) $\mathrm{CO}_{2} \mathrm{EOR}$ 의 경우, 주입 $\mathrm{CO}_{2}$ 와 원유 가 완전히 혼화됨으로써 유체의 점성도 감소, 유동성의 증가 및 표면장력의 해소로 인한 상대투과특성의 향상 등의 효과로 인해 잔류 원유를 재유동시켜 회수율을 증 진시키게 된다.

비혼화(immiscible) $\mathrm{CO}_{2} \mathrm{EOR}$ 의 경우, $\mathrm{CO}_{2}$ 로 포화된 원유가 팽창함에 따라 점성도의 감소와 함께 저류층 내 압력증가로 회수율이 증가하는 원리이다. Fig. 3은 전세 계 $\mathrm{CO}_{2} \mathrm{EOR}$ 프로젝트 수의 연도별 추이를 나타낸 것 으로 대부분의 $\mathrm{CO}_{2} \mathrm{EOR}$ 은 상대적으로 회수율이 우수 한 혼화 형태로 실시되고 있음을 알 수 있다. 1 톤의 원 유 회수율 증진을 소요되는 $\mathrm{CO}_{2}$ 주입량은 혼화 조건에 서 1 3 $\mathrm{CO}_{2}$-Tonnes인데 반해, 비혼화 조건에서는 3 5 $\mathrm{CO}_{2}$-Tonnes 인 것으로 알려져 있다(NETL, 2010). 다만, 혼화 $\mathrm{CO}_{2} \mathrm{EOR}$ 을 수행하기 위해서는 주입 $\mathrm{CO}_{2}$ 와 저류층 내 원유가 충분히 혼화되는 최소혼화압력 (Minimum Miscible Pressure, MMP) 이상으로 $\mathrm{CO}_{2}$ 를 주입하여야 한다.

$\mathrm{MMP}$ 의 측정 방법으로는 slim tube method와 rising bubble method가 대표적이다(Elsharkawy et al., 1992). Slim tube method에서는 대상 원유로 암석 시료를 포 화시킨 후 주입압을 변화시켜가면서 $\mathrm{CO}_{2}$ 를 주입한다. 이러한 $\mathrm{CO}_{2}$ flooding 과정 중 회수되는 원유량을 측정 하여 초기 원유량의 $95 \%$ 이상 회수되는 시점의 압력을 $\mathrm{MMP}$ 로 정의한다. $\mathrm{CO}_{2} \mathrm{EOR}$ 의 현장 적용 및 원유 회 수율 증진을 위해서는 실내 실험을 통하여 대상 유전의 원유 특성 및 저류층 내 지질조건을 고려한 $\mathrm{MMP}$ 를 정 확하게 예측하여야 한다.

$\mathrm{CO}_{2} \mathrm{EOR}$ 에서 예상되는 문제점으로는 핑거링(Fingering) 현상이 발생하여 스윕효율(Sweep Efficiency)이 저하 되는 것을 들 수 있다. 핑거링 현상은 주입 $\mathrm{CO}_{2}$ 의 점성 도가 원유에 비해 상대적으로 낮기 때문에 원유와의 접 촉 효율이 떨어져 원유를 밀어내지 못하고 다량의 잔류 원유가 발생하게 되는 현상을 말한다(Fig. 4a). 또한, 주 입정과 생산정 사이에 대규모의 단층대가 존재하는 경우 $\mathrm{CO}_{2}$ 의 파과(Breakthrough)가 발생하여 잔류 원유가 생 길 수 있다(Fig. 4b). 한편, 이상적인 $\mathrm{CO}_{2} \mathrm{EOR}$ 효과는 Fig. $4 \mathrm{c}$ 와 같다. 이러한, 핑거링 및 파과에 의한 원유 회 수 효율 감소를 방지하기 위하여 물과 $\mathrm{CO}_{2}$ 를 일정 주기 간격으로 교대로 주입하는 Water Alternating Gas (WAG) 공법이 사용되기도 한다. WAG 공법은 초임계 상태 $\mathrm{CO}_{2}$ 와 같이 유체의 점성을 직접적으로 높이기보 다는 유체의 유효투과능을 낮추는 간접적 $\mathrm{CO}_{2}$ 유동 제 어방법에 해당한다(Fig. $4 \mathrm{~d}$ ). 한편, WAG 공법의 현장 적용 과정에서는 $\mathrm{CO}_{2}$ 주입에 상대적으로 많은 시간이 소요되고 저류층 내 물 포화도의 증가로 인해 $\mathrm{CO}_{2}$ 와 원 유가 잘 혼화되지 않는 단점이 있다. 이외에도 $\mathrm{CO}_{2}$-폼 (Foam)을 주입하여 유동성을 감소시키거나 폴리머를 혼합하여 점성을 증가시키는 방법도 적용되고 있다.

$\mathrm{CO}_{2} \mathrm{EOR}$ 적용과정에서 주입 압력이 지나치게 높을 경우, 저류층 및 상부 덮개암, 지상 구조물의 안정성에

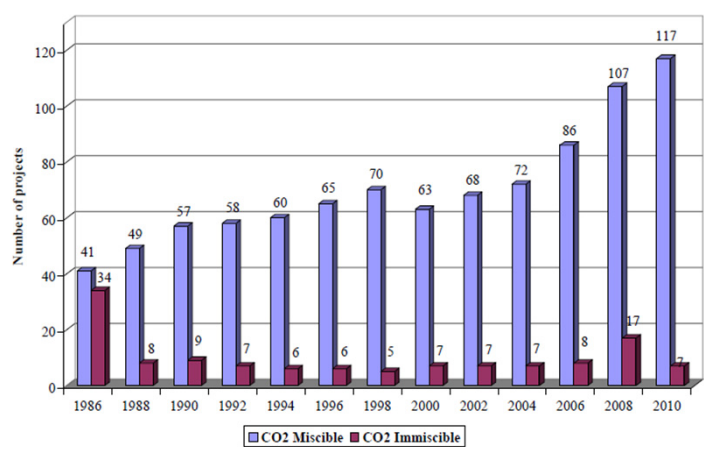

Fig. 3. Trend of miscible and immiscible $\mathrm{CO}_{2}$ EOR projects (Andrei et al., 2010) 
영향을 미칠 수 있다. $\mathrm{CO}_{2}$ 주입과정에서 고려해야할 주 요 암반공학적 쟁점들로는 주입정 주변 단층의 재활성화 (fault reactivation)와 이로 인한 주입 $\mathrm{CO}_{2}$ 의 누출, 덮개 암 손상(caprock fracturing)에 의한 주입 $\mathrm{CO}_{2}$ 의 누출, 주입정의 역학적 안정성(wellbore stability), 주입정 상 부 지표면의 융기(surface ground uplift)에 따른 지상구
조물에의 피해, 주입에 의한 지진발생 등이 있다(Kim et al., 2008; 박의섭 외, 2012). Fig. 5는 $\mathrm{CO}_{2}$ 주입에 따른 저류층 내 응력 분포 변화에 이에 따른 덮개암 내 인장 균열 발생, 덮개암과 저류암 경계면에서의 전단균열 발 생 및 주변 단층의 활성화 가능성을 도시화 한 것이다. $\mathrm{CO}_{2}$ 주입실시 전에 이들 요소들에 대한 정확한 사전

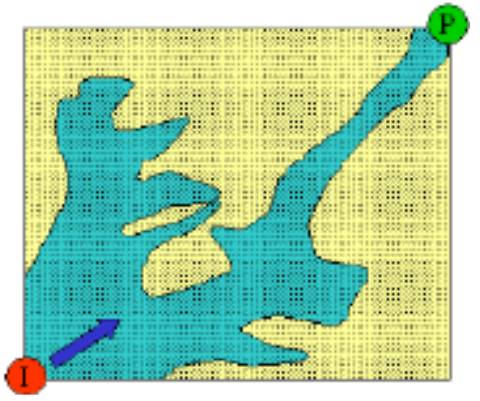

(a) Fingering of injected $\mathrm{CO}_{2}$

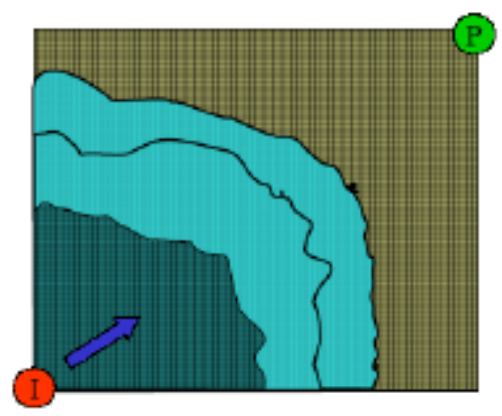

(c) Ideal $\mathrm{CO}_{2}$ flooding

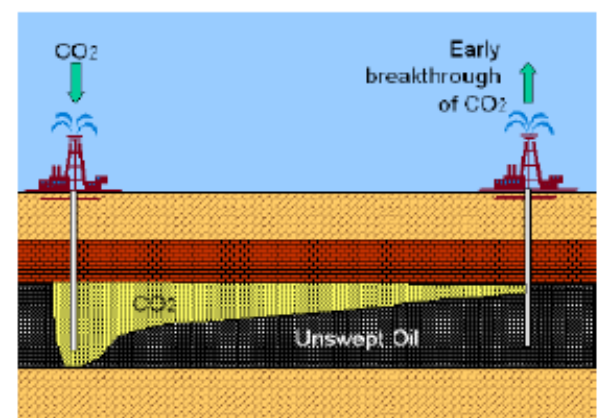

(b) $\mathrm{CO}_{2}$ breakthrough

Simplied Well Cross-section

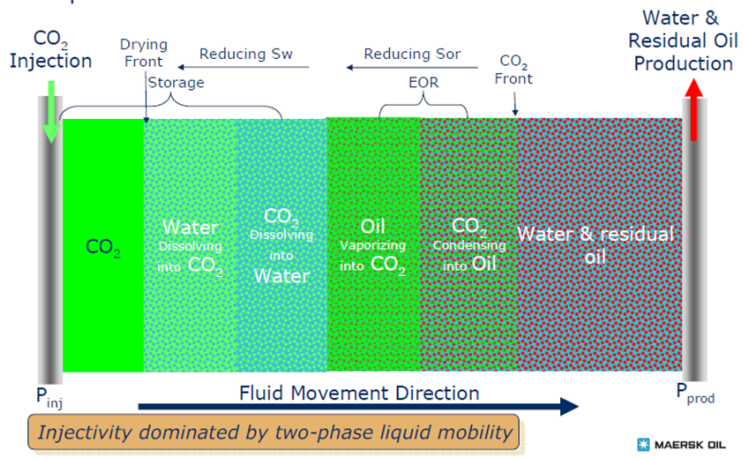

(d) Simplified well cross-section during WAG

Fig. 4. $\mathrm{CO}_{2}$ flows from injection well (I) to production well (P) (Deepak, 2009)

Injection-induced stress, strain and deformation

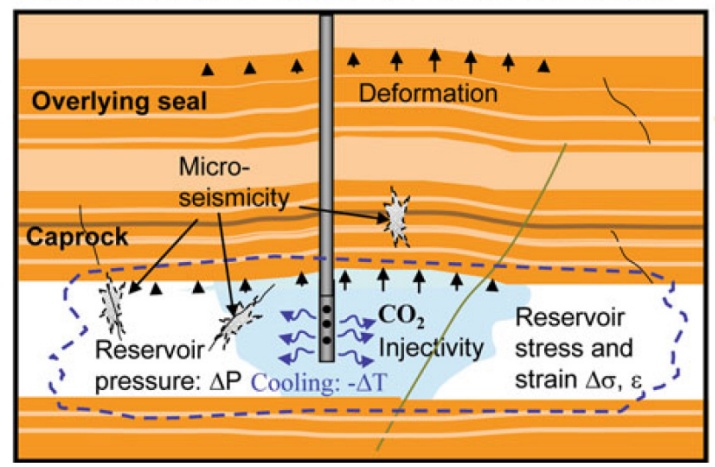

Unwanted mechanical changes

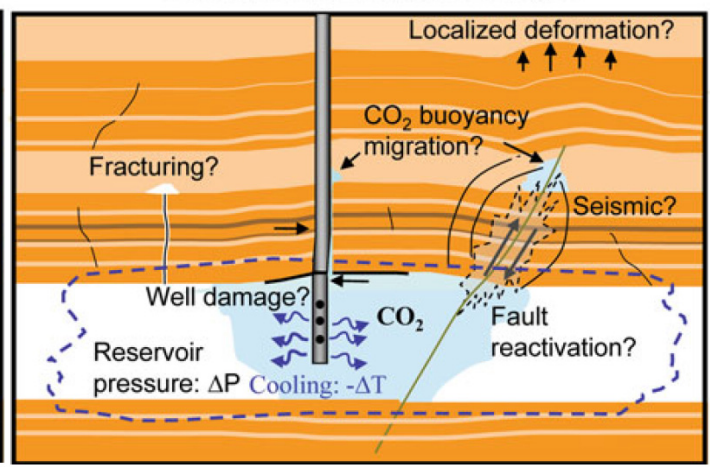

Fig. 5. Geomechanical issues during $\mathrm{CO}_{2}$ injection (after Rutqvist, 2012) 
예측 평가가 실시되어야 하며 이를 위해서는 주입 $\mathrm{CO}_{2}$, 지하수, 원유 등의 다양한 유체 유동 및 지하 심부의 고 온 고압(High Temperature High Pressure, HTHP) 조 건에서의 역학적 거동을 시뮬레이션할 수 있는 해석기 법을 활용하여 현장 지질조건의 불확실성을 고려한 다 양한 시나리오 해석을 통해 저류층 주변의 역학적 안정 성을 유지할 수 있는 최대주입압력(Maximum Injection Pressure, MIP)이 사전 설계되어야 한다. 따라서, $\mathrm{CO}_{2}$ $\mathrm{EOR}$ 에서의 적정 $\mathrm{CO}_{2}$ 주입압력은 $\mathrm{MMP}$ 와 $\mathrm{MIP}$ 범위 내에서 적절히 설계되어야 함을 알 수 있다.

\section{3. $\mathrm{CO}_{2} \mathrm{EOR}$ 기술 경제성}

SBI(2010)에 의하면 2011년에 전서계에서 EOR로

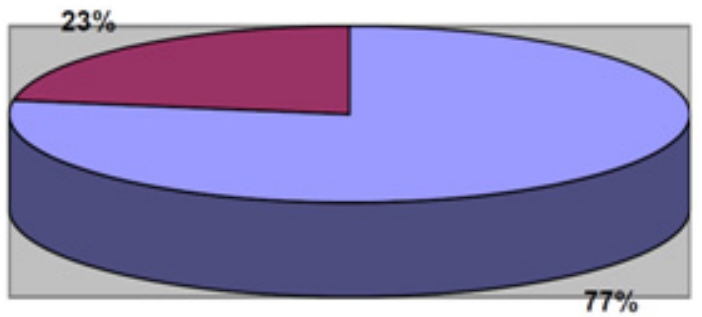

Low Price $(50 \$ / B)$

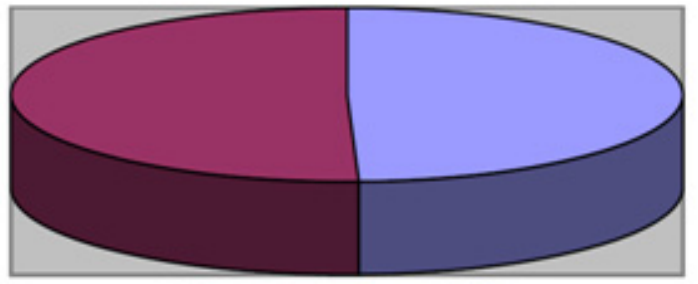

$51 \%$

High Price (150\$/B)
생산되는 원유 비율은 3.3\% 수준이지만 2015년에는 7 9배 성장한 11.1 billion barrels로 약 34\%까지 상승 할 것으로 예측된다(총 생산량은 35.4 billion barrels, 원유가격은 $110 \$ / B a r r e l$ 로 가정). 또한, $\mathrm{EOR}$ 에 의한 원 유 생산량은 원유가가 낮은 $50 \$ / b a r r e l$ 인 비관안의 경우 $23 \%$, 고유가 $(150 \$ / \mathrm{barrel})$ 인 낙관안의 경우 $49 \%$ 를 차 지할 것으로 전망되고 있다(Fig. 6).

또한, 육상 $\mathrm{CO}_{2} \mathrm{EOR}$ 의 경제성 분석 결과에 의하며 $\mathrm{CO}_{2} 1$ 톤당 $45 \$$, 원유가 $70 \$ / \mathrm{barrel}$ 인 조건에서 대략 $15 \sim 25 \$$ Barrel의 이익 마진을 가지는 것으로 분석된 바 있다(Table 2).

Fig. 7은 $\mathrm{CO}_{2} \mathrm{EOR}$ 과정에서 일반적으로 관측되는 원유 생산량과 $\mathrm{CO}_{2}$ 소비량의 관계를 보여준다. $\mathrm{CO}_{2}$ $\mathrm{EOR}$ 초기 단계에서 상대적으로 많은 양의 $\mathrm{CO}_{2}$ 주입이

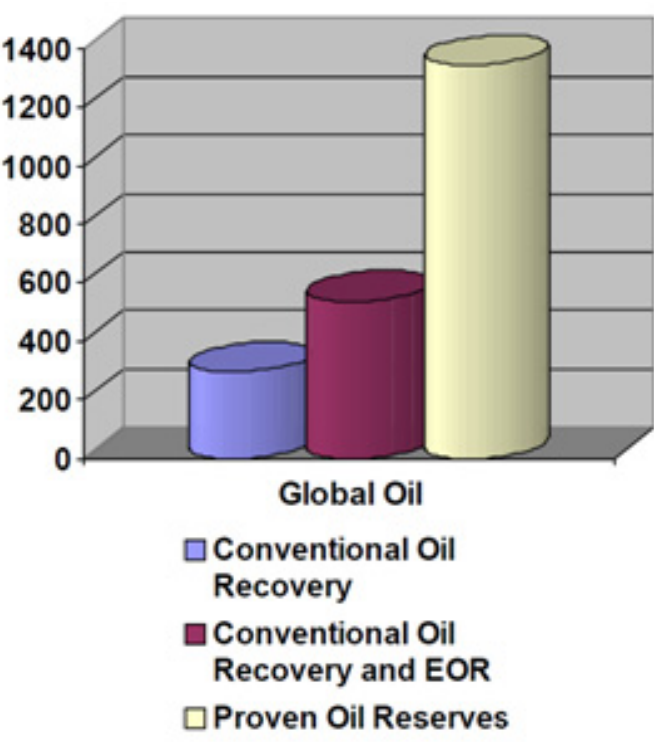

Fig. 6. EOR market estimate according to oil prices (SBI, 2010)

Table 2. Illustrative costs and economics of a $\mathrm{CO}_{2}$ EOR project (NETL, 2010)

\begin{tabular}{c|c}
\hline \hline Oil Price (\$/Barrel) & $\$ 70$ \\
\hline Gravity/Basis Differentials, Royalties and Production Taxes & $(\$ 15)$ \\
\hline Net Wellhead Revenes $(\$ /$ Barrel) & $\$ 55$ \\
\hline Capital Cost Amortization & $(\$ 5$ to $\$ 10)$ \\
\hline $\mathrm{CO}_{2}$ Costs $(\$ 2 /$ Mcf for purchase; $\$ 0.70 /$ Mcf for recycle) & $(\$ 10$ to $\$ 15)$ \\
\hline Well/Lease Operations and Maintenance & $\$ 15$ to $\$ 25$ \\
\hline Economic Margin, Pre-Tax $(\$ /$ Barrel $)$ &
\end{tabular}

( )안은 비용 발생분을 나타냄 
이루어지며 이후 원유 생산 증진 효과가 가시화되기 까 지는 약 18-24개월가량이 소요된다. 이후 $\mathrm{CO}_{2}$ 주입량 을 늘림에 따라 원유 생산량도 비례해서 증가하지만 peak 이후에는 점진적으로 생산량이 감소하게 된다. 초 기 주입된 $\mathrm{CO}_{2}$ 의 일부(30 70\%)는 원유 생산과 함께 다시 회수되어 재분리 과정을 거쳐 다시 주입하게 되므 로 장기적 운영 과정에서는 재분리 $\mathrm{CO}_{2}$ 의 양이 상대적 으로 많아진다. 따라서, $\mathrm{CO}_{2} \mathrm{EOR}$ 프로젝트는 운영 초 기에는 원유 회수 증진에 초점을 두어 $\mathrm{CO}_{2}$ 를 주입하여 재분리-재주입하는 과정을 반복하고 생산량 감소추이 에 따라 장기적으로는 $\mathrm{CCS}$ 목적으로 전환하는 방식으 로 운영하게 된다.

국내 $\mathrm{CO}_{2} \mathrm{EOR}$ 시장은 향후 해상 가스전을 중심으로 형성될 수 있을 것으로 보인다. $\mathrm{CO}_{2} \mathrm{EOR}$ 관련 요소 기 술은 다수 개발되어 있으나, 이들 요소 기술들을 $\mathrm{CO}_{2}$ $\mathrm{EOR}$ 목적으로 통합하고 국내 육상현장을 대신하여 해

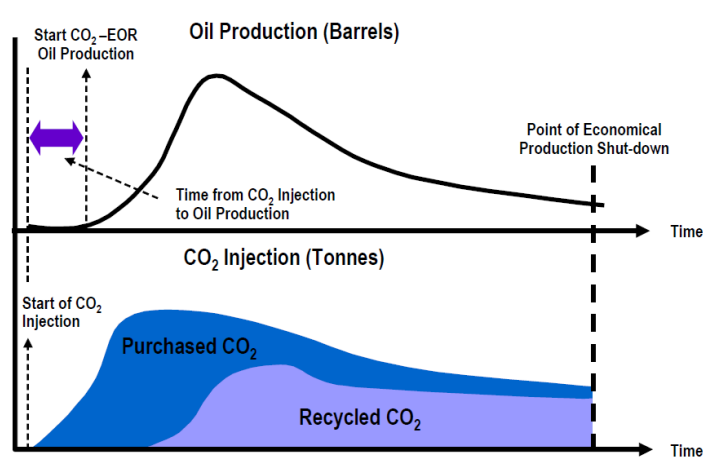

Fig. 7. Profiles for $\mathrm{CO}_{2}$ injection and oil production in $\mathrm{CO}_{2}$ EOR (Bellona, 2005)
외 유전을 대상으로 현장 기술실증을 실시하고 운영경 험을 축적함으로써 해상 가스전에의 확대 적용 및 해외 $\mathrm{CO}_{2} \mathrm{EOR}$ 시장에까지 진출할 수 있을 것으로 기대된 다. Table 3 은 전세계의 $\mathrm{CO}_{2} \mathrm{EOR}$ 대상부지 분석 결과 를 요약한 것으로 중동 및 북아프리카 지역에서 $\mathrm{CO}_{2}$ $\mathrm{EOR}$ 시장의 급격한 성장이 예상됨을 알 수 있다.

Table 4는 염수대수층에의 $\mathrm{CO}_{2}$ 저장과 $\mathrm{CO}_{2} \mathrm{EOR}$ 의 특징을 비교한 것이다. $\mathrm{CO}_{2} \mathrm{EOR}$ 의 경우, 오랜 지질학 적 시간동안 원유가 생성 축적된 것이므로 $\mathrm{CO}_{2}$ 저장을 위한 지질구조에 대한 불확실성이 상대적으로 낮은 특 징이 있다. 또한, 생산정에서의 원유 회수량 조절을 통 해 저류층 내 압력을 능동적으로 조절할 수 있어 주입 에 의한 공극내 유체 압력 영향 영역을 최소화할 수 있 는 장점이 있다. 또한, $\mathrm{CO}_{2}$ 주입을 통한 원유 회수 증진 효과는 단순 $\mathrm{CCS}$ 과정에서의 포집에 소요되는 비용을 보상함으로써 $\mathrm{CCS}$ 의 경제성을 향상시키는 효과를 얻 을 수 있다. 그리고, 기존 원유 생산지역에 $\mathrm{CO}_{2}$ 만 추가 주입하게 되므로 $\mathrm{CCS}$ 를 위한 신규 인허가 절차를 간소 화할 수 있을 뿐만 아니라 주민 수용성을 향상시키는 효과도 기대할 수 있다.

\section{Weyburn $\mathrm{CO}_{2} \mathrm{EOR}$ 프로젝트 사례}

Weyburn $\mathrm{CO}_{2} \mathrm{EOR}$ 프로젝트는 천연가스 생산과정에 서 얻어진 자연발생적 $\mathrm{CO}_{2}$ 가 아닌 석탄가스화발전소에 서 대규모로 포집한 인위적 $\mathrm{CO}_{2}$ 공급원을 이용한 최초 의 $\mathrm{CO}_{2} \mathrm{EOR}$ 프로젝트로서의 의의를 가진다. WeyburnMidale 유전은 캐나다 중부에서 미국 북부 지역에 걸쳐 위치하며(Fig. 8) 1954년부터 원유 생산을 시작하여 현재

Table 3. Estimated $\mathrm{CO}_{2}$ Storage Potential from the Application of "State-of-the-Art" $\mathrm{CO}_{2}$-EOR in World Oil Basins (Advanced Resources International Inc., 2009)

\begin{tabular}{l|c|c|cc}
\hline \multicolumn{1}{c|}{ Region name } & $\begin{array}{c}\mathrm{CO}_{2} \mathrm{EOR} \text { Oil Recovery } \\
(\mathrm{MMBO})\end{array}$ & $\begin{array}{c}\text { Miscible Basin } \\
\text { Count }\end{array}$ & $\begin{array}{c}\mathrm{CO}_{2} \text { Oil Ratio } \\
\text { (tonnes/Bbl) }\end{array}$ & $\begin{array}{c}\mathrm{CO}_{2} \text { stored } \\
(\mathrm{Gigatonnes})\end{array}$ \\
\hline Asia Pacific & 18,376 & 6 & 0.27 & 5.0 \\
\hline Central and South America & 31,697 & 6 & 0.32 & 10.1 \\
\hline Europe & 16,312 & 2 & 0.29 & 4.7 \\
\hline Former Soviet Union & 78,715 & 11 & 0.27 & 21.6 \\
\hline Middle East and North Africa & 230,640 & 3 & 0.30 & 70.1 \\
\hline North America/ Non-U.S. & 18,080 & 14 & 0.29 & 5.9 \\
\hline United States & 60,204 & 0 & N/A & 17.2 \\
\hline South Asia & - & 2 & 0.30 & - \\
\hline Sub-Saharan Africa and Antarctica & 14,505 & 50 & 0.30 & 4.4 \\
\hline Total & 468,530 & & & 139.0 \\
\hline
\end{tabular}


Table 4. Comparison of generalized risk elements for sequestration in brine formations, with generalized risk elements for $\mathrm{CO}_{2}$ EOR (Hovorka \& Tinker, 2010)

\begin{tabular}{|c|c|c|}
\hline Risk element & Sequestration in brine formation & $\mathrm{CO}_{2} \mathrm{EOR}$ \\
\hline Well operation & $\begin{array}{l}\mathrm{CO}_{2} \text { injection (possible brine } \\
\text { production) }\end{array}$ & $\begin{array}{l}\mathrm{CO}_{2} \text { injection }+ \text { oil, brine, } \mathrm{CO}_{2} \text { production, with } \\
\text { recycle }\end{array}$ \\
\hline Area of review & Large areas of pressure elevation & $\begin{array}{l}\text { Active pressure control through production, } \\
\text { smaller magnitude pressure increase, and smaller } \\
\text { area of elevated pressure }\end{array}$ \\
\hline $\begin{array}{l}\text { Injection zone performance in } \\
\text { accepting fluids }\end{array}$ & $\begin{array}{l}\text { inferred from sparse well data } \\
\text { and relatively short duration } \\
\text { hydrologic tests }\end{array}$ & $\begin{array}{l}\text { Well known, many wells and extensive fluid } \\
\text { production history with information on how the } \\
\text { reservoir responded }\end{array}$ \\
\hline Confining system performance & Inferred & Demonstrated \\
\hline Structural or stratigraphic trapping & May or may not be part of system & Demonstrated \\
\hline Dissolution of $\mathrm{CO}_{2}$ into fluids & Moderate & High \\
\hline $\begin{array}{l}\text { Wells that penetrate the confining } \\
\text { system }\end{array}$ & Usually sparse & Usually dense \\
\hline Financial support for injection & All costs & Costs + revenue from oil production \\
\hline $\begin{array}{l}\text { Permitting and pore-space } \\
\text { ownership }\end{array}$ & $\begin{array}{l}\text { Evolving, state-dependent and } \\
\text { uncertain, between water law and } \\
\text { mineral law }\end{array}$ & $\begin{array}{l}\text { Historic frameworks for secondary and tertiary } \\
\text { recover are well known }\end{array}$ \\
\hline Public acceptance & Uncertain & $\begin{array}{l}\text { Relatively good because of royalties, fee for surface } \\
\text { access, and jobs are recognized in host community }\end{array}$ \\
\hline
\end{tabular}

WILLISTON BASIN

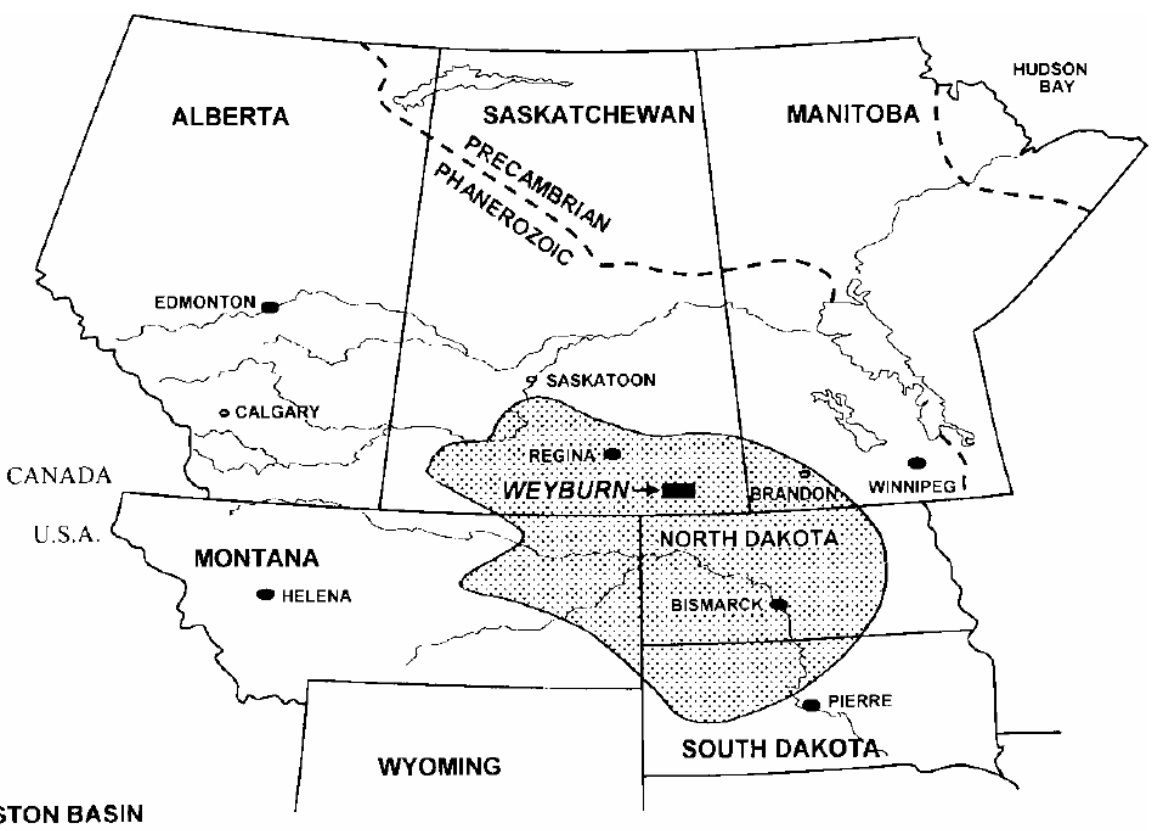

Fig. 8. Location of Weyburn field for $\mathrm{CO}_{2}$ EOR (Mourits, 2008)

까지 약 630여 개의 생산정 및 주입정이 시추되었다. 이 곳에서의 평균 1 일 원유 생산량은 약 18,200 barrels/ day 로, 이는 캐나다 연간 원유 생산량의 $10 \%$ 에 해당한다.
1차 및 2차 생산과정을 거치면서 저류층 내 공급압력은 운영 초기 $14 \mathrm{MPa}$ 에서 $2-6 \mathrm{MPa}$ 수준까지 감소하여 원 유 생산량이 감소함에 따라 2000년부터 $\mathrm{CO}_{2}$ 주입에 의 
한 회수 증진을 실시하고 있다. 회수 증진을 위한 주입 과정에서의 공급압력은 최대 $23 \sim 25 \mathrm{MPa}$ 수준까지 증 가한 것으로 보고되었다. Table 5 및 Table 6은 Weyburn-Midale 지역의 지질특성 및 운영조건을 나타 낸다.

Weyburn에서의 $\mathrm{CO}_{2}$-EOR 사업은 미국 Dakota의 석 탄가스화발전소에서 포집한 $\mathrm{CO}_{2}$ 를 길이 $325 \mathrm{~km}$ 의 파 이프라인을 통해 캐나다 Weyburn과 Midale 지역의 석 유 회수 증진에 사용하는 프로젝트이다. 1 일 $\mathrm{CO}_{2}$ 생산 량은 13,000 톤으로 이중 8,000 톤을 EOR 목적으로 파 이프라인으로 수송하여 주입하고 있다. 수송압은 약 6.9 $\mathrm{MPa}$ 이며, 평균 주입량은 $2.5 \mathrm{MtCO}_{2} / \mathrm{year}$, 순도는 $95 \%$
$\left(\mathrm{H}_{2} \mathrm{~S}\right.$ 함유량 $2 \%$ 이내)로 보고되었다. 2010 년 총 원유 회수량은 $16,500 \mathrm{barrel} / \mathrm{day}$ 로 약 $34 \%$ 의 원유 회수량 증진 효과를 얻고 있는 것으로 알려져 있다. 주입 $\mathrm{CO}_{2}$ 의 약 $67 \%$ 에 해당하는 $1,600 \mathrm{CO}_{2}$ kilo-tonnes/year를 저장할 수 있다.

Weyburn 유전은 매장량 1.4 billion barrel 규모이며 1954년에 발견되었다. 1962년에 water flooding을 적용 하였으며, 1990년대에 horizontal infill drilling 프로그 램이 진행된 이후에도 생산량이 감소하였다. 이후 2000 년 8 월부터 $\mathrm{CO}_{2} \mathrm{EOR}$ 공법을 적용하여 25년간 적용하 여 OOIP의 $15 \%$ 정도가 추가 회수될 것으로 예측되고 있다(Fig. 9).

Table 5. Oil field characteristics of Weyburn and Midale $\mathrm{CO}_{2}$-EOR site (Mourits, 2008)

\begin{tabular}{|c|c|c|}
\hline & "Weyburn (EnCana) & Midale (Apache) \\
\hline Field Size & $180 \mathrm{~km}^{2}$ & $104 \mathrm{~km}^{2}$ \\
\hline Depth & $1500 \mathrm{~m}$ & $1500 \mathrm{~m}$ \\
\hline Cross Pay/ Net Pay & $25 / 7.8 \mathrm{~m}$ & $22 / 7.5 \mathrm{~m}$ \\
\hline Zone Porosity & \multicolumn{2}{|c|}{$\begin{array}{l}\text { Marley Dolomite Zone: } 26 \% \\
\text { Vuggy Limestone Zone: } 15 \%\end{array}$} \\
\hline Average Porosity & $17.2 \%$ & $16.3 \%$ \\
\hline Zone Permeability & \multicolumn{2}{|c|}{$\begin{array}{l}\text { Marley Dolomite Zone: } 10 \mathrm{mD} \\
\text { Vuggy Limestone Zone: } 30 \mathrm{mD}\end{array}$} \\
\hline Average Water Saturation & $31.7 \%$ & $16.3 \%$ \\
\hline Average Oil Gravity & 29.3 API $\left(880 \mathrm{~kg} / \mathrm{m}^{3}\right)$ & 29.8 API $\left(877 \mathrm{~kg} / \mathrm{m}^{3}\right)$ \\
\hline Minimum Miscible Pressure & \multicolumn{2}{|c|}{$14 \sim 16 \mathrm{MPa}$} \\
\hline Original Oil in Place & 1.4 billion bbl & 515 million bbl \\
\hline $\begin{array}{c}\text { Oil Recovery Pre-EOR } \\
\text { (Primary, Waterflood, Infill) }\end{array}$ & $370 \mathrm{bbl}(26.4 \%$ OOIP $)$ & $154 \mathrm{bbl}(25.4 \%$ OOIP $)$ \\
\hline Number of Injector Wells & $\mathrm{N} / \mathrm{A}$ & $60-70$, incl. $10 \mathrm{CO}_{2}$ \\
\hline Number of Production Wells & 360 (in EOR area) & 270 (total field) \\
\hline
\end{tabular}

Table 6. Operating characteristics of Weyburn and Midale $\mathrm{CO}_{2}$-EOR site (Mourits, 2008)

\begin{tabular}{c|c|c}
\hline \hline & Weyburn (EnCana) & Midale (Apache) \\
\hline Start of $\mathrm{CO}_{2}$ injection / duration & $2000 / 30$ years & $2005 / 30$ years \\
\hline Injection Pressure & \multicolumn{2}{|c}{$10 \sim 11 \mathrm{MPa}$} \\
\hline $\begin{array}{c}\text { Injection of source } \mathrm{CO}_{2} \\
\text { recycle of } \mathrm{CO}_{2} \& \text { produced Gas }\end{array}$ & $\begin{array}{c}6,500 \mathrm{t} / \mathrm{d}(125 \mathrm{MMscf} / \mathrm{d}) \\
60 \mathrm{MMscf} / \mathrm{d}\end{array}$ & $\begin{array}{c}1,300 \mathrm{t} / \mathrm{d}(25 \mathrm{MMscf} / \mathrm{d}) \\
6 \sim 8 \mathrm{MMsc} / \mathrm{d}\end{array}$ \\
\hline Annual amount of source $\mathrm{CO}_{2}$ injected & 2.4 million tonnes & 474,000 tonnes \\
\hline Total Amount of Source $\mathrm{CO}_{2}$ injected to date & 17 million tonnes (December 2010) & 2.1 million tonnes (May 2010) \\
\hline Incremental Oil Production & $18,000 \mathrm{~b} / \mathrm{d}$ for EOR area & N/A \\
\hline Projected total incremental oil recovery due to $\mathrm{CO}_{2}$ & $150,600 \mathrm{~b} / \mathrm{d}$ for total unit & 60 million barrels (17\% OOIP) \\
\hline $\mathrm{CO}_{2}$ utilization factor & $3 \sim 4$ Mcf/b & 2.3 Mcf/b \\
\hline Projected amount of $\mathrm{CO}_{2}$ stored at project & $30+$ million tonnes (gross) & $10+$ million tonnes (gross) \\
completion & $26+$ million tonnes (net) & $8.5+$ million tonnes (net) \\
\hline Total capital cost of EOR project & CAD\$1 billion & CAD\$95 million
\end{tabular}


$\mathrm{CO}_{2}$ 주입에 따른 대표적 지반의 역학적 변형으로는 지표면 융기와 미소지진 발생을 들 수 있다. $\mathrm{CO}_{2}$ 주입

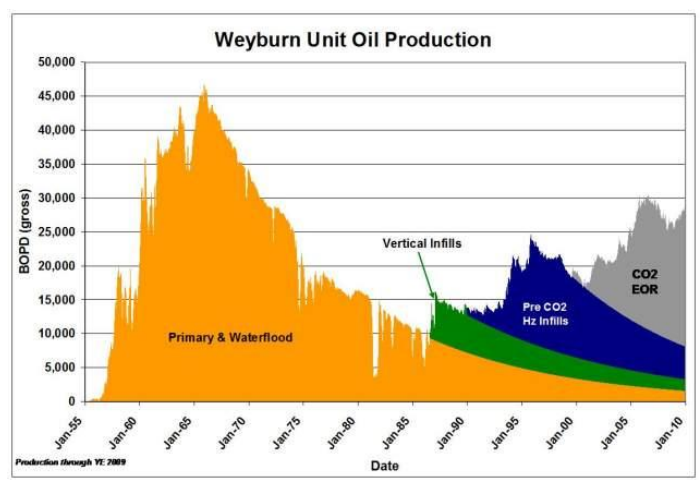

Fig. 9. Oil production data at Weyburn area (Mouritas, 2008)

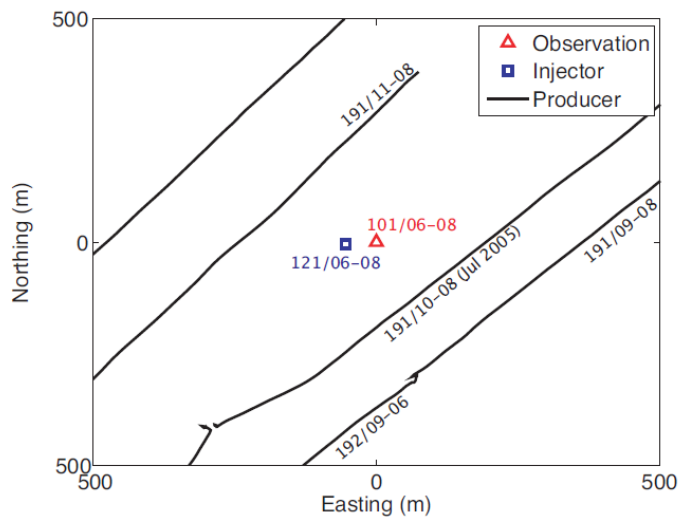

(a) Miscroseismic monitoring setup at Weyburn site

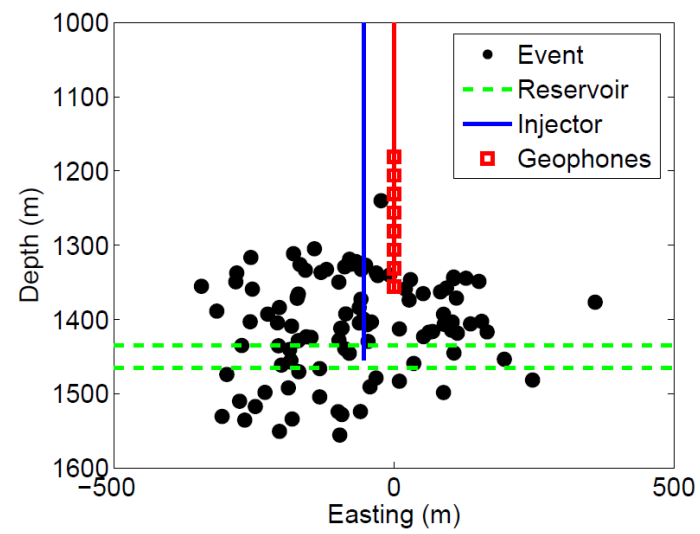

(c) Cross section view of detected miscroseismic event during the Phase IB at Weyburn site
에 의한 지표면 융기 관측 사례로는 알제리 In Salah에 서의 육상 가스전에의 $\mathrm{CO}_{2}$ 주입 후 인공위성을 이용한 $\mathrm{InSAR}$ 관측이 대표적으로 지표면 변위량을 관측결과 최 대 $15 \mathrm{~mm}$ 까지의 지표면 융기를 관측한 바 있다(Onuma \& Ohkawa, 2009).

Weyburn 프로젝트는 미소지진(miscroseimic) 관측 을 통해 주입 $\mathrm{CO}_{2}$ 의 유동 범위 파악 및 상부 덮개암, 저류층의 파괴양상을 파악하고자 한 최초의 $\mathrm{CCS}$ 프로 젝트라는 의의를 가진다. Fig. 10 및 Fig. 11은 WeyburnMidale 지역에서 $\mathrm{CO}_{2}$ 주입시 관측된 미소지진 모니터 링 결과를 나타낸다. Weyburn 프로젝트에서는 $\mathrm{CO}_{2}$ 주 입시의 미소지진 모니터링을 위해 주입정(Fig. $10 \mathrm{a}$ 의 121/06-08)으로부터 $50 \mathrm{~m}$ 떨어진 관측용 시추공(Fig. $10 \mathrm{a}$ 의 101/06-08)에 3성분 지오폰(geophone)을 관측 용 시추공 심도 $1181.5 \mathrm{~m} \sim 1356.5 \mathrm{~m}$ 구간 8개소에 설

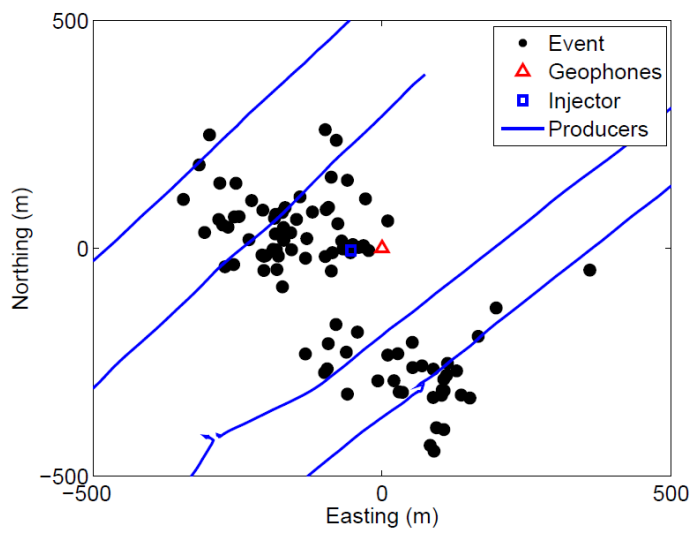

(b) Plane view of detected miscroseismic event during the Phase IB at Weyburn site

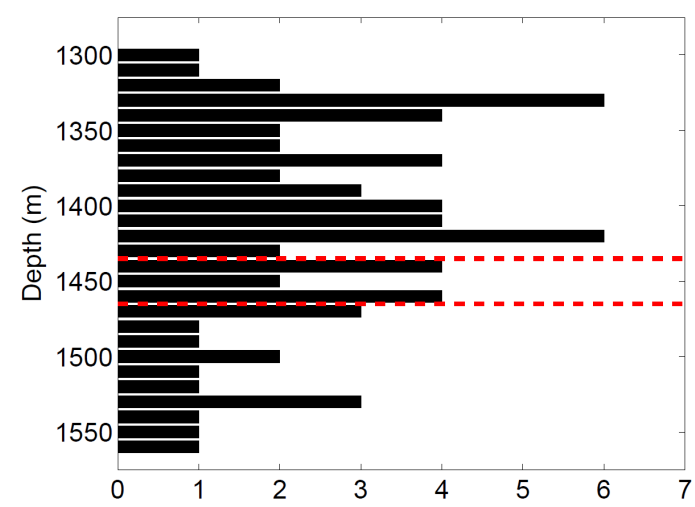

(d) Histogram of depths of detected miscoseismic event during the Phase IB at Weyburn site

Fig. 10. Results of microseismic monitoring during $\mathrm{CO}_{2}$ injection for $\mathrm{EOR}$ at Weyburn site (Verdon, 2010) 


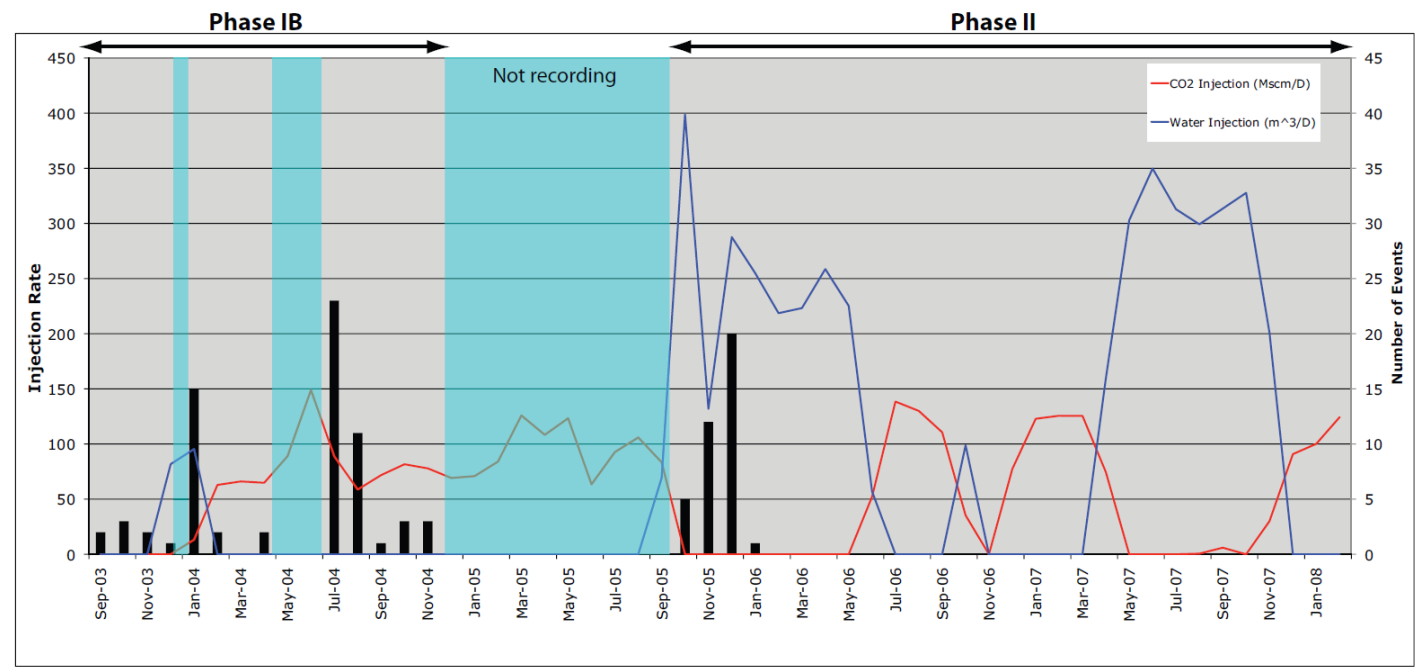

Fig. 11. $\mathrm{CO}_{2}$ (red) and water (blue) injection rate and detected miscroseismic event rate at Weyburn site (Verdon, 2010)

치하였다(Fig. 10c). $\mathrm{CO}_{2}$ 주입은 2000년부터 시작하 였으나 다운홀(downhole) 지오폰을 이용한 미소지진 모니터링은 2003년부터 개시하여 5년 동안의 모니터 링 기간동안 총 86 개의 미소지진을 관측하였다(Fig. 11). 이들 발생 미소지진의 진원 추적 결과, 대부분의 미소지진 거동은 주입정과 생산정 주변 저류층 상부 피 복암(overburden)에서 발생한 것으로 추정되었으며 (Fig. 10d), 특히 수직 방향의 주입정보다 수평 방향의 생산정 주변 영역에서 상대적으로 많은 미소지진이 발 생한 것으로 파악되었다. 미소지진 발생은 취성재료 내에서의 전단파괴 양상을 설명하는 균열 잠재성(fracture potential) 지수를 이용하여 간략하게 파악할 수 있다 (Connolly \& Cosgrove, 1999). 균열 잠재성 지수 $\left(\mathrm{f}^{\mathrm{p}}\right)$ 는 유체 주입에 따른 공극압력의 변화 및 재분배된 응 력 상태와 Mohr-Columb 파괴곡선과의 근사정도를 나 타내며 축차응력 $(q)$ 과 임계축차응력 $\left(q_{c r i t}\right)$ 의 비로 정의된 다 $\left(f^{p}=q / q_{c r i t}\right)$. 여기서, $q=\sigma_{1}^{\prime}-\sigma_{3}^{\prime}, q_{c r i t}=2\left(C \cos \phi_{f}+\right.$ $+p \sin \phi_{f}$ )와 같다. $\sigma_{1}^{\prime}$ 및 $\sigma_{3}^{\prime}$ 는 최대, 최소 유효주응력, $C$ 는 점착력, $\phi_{f}$ 는 내부마찰각, $p$ 는 $\left(\sigma^{\prime}{ }_{1}+\sigma^{\prime}{ }_{2}+\sigma^{\prime}{ }_{3}\right) / 3$ 로 정의되는 평균주응력을 나타낸다. Verdon et al.(2011) 은 Weyburn 지역의 덮개암 및 저류층에서의 점착력과 내부마찰각을 각각 $C=5 \mathrm{MPa}, \phi_{f}=45^{\circ}$ 및 $C=3.5 \mathrm{MPa}$, $\phi_{f}=40^{\circ}$ 로 정의하고 주입정과 생산정 주변에서 상대적 으로 미소지진 발생가능성이 높고 저류층보다는 상부 덮개암에서 미소지진이 많이 발생함을 응력해석을 통 해 설명하였다(Fig. 12).

한편, 일반적으로 미소지진 발생영역 및 궤적추적을

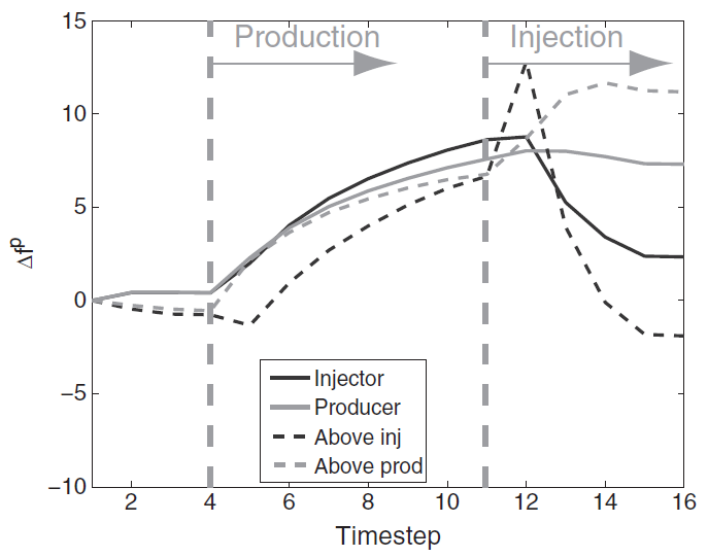

Fig. 12. Fracature potential in Weyburn reservoir (Verdon et al, 2011)

통해 주입 유체의 유동양상을 파악할 수 있는 것으로 알려져 있다. 그러나 Weyburn 지역의 경우, $\mathrm{CO}_{2}$ 주입에 의해 상부 덮개암에서 상대적으로 많은 미소지진이 관 측되었음에도 불구하고 3D 시간경과 탄성파탐사(TimeLapse Seismic Survey)를 통한 주입 저류층으로부터의 $\mathrm{CO}_{2}$ 누출은 확인되지 않았다. Verdon et al. (2011)은 이를 유체 유동에 의한 미소지진 발생메커니즘이 아닌 $\mathrm{CO}_{2}$ 주입에 따른 과잉공급압력이 아칭효과(arching effect)를 통해 상부 덮개암으로 전달되어 기존 균열이 변형되어 발생하는 것으로 설명하고 있다. 따라서, Weyburn 프로젝트 미소지진 관측결과만을 가지고 주 입 $\mathrm{CO}_{2}$ 의 누출 가능성을 평가하기에는 한계가 있음을 
알 수 있으며 정확한 누출여부 파악을 위해서는 저류층 내 유체 및 주입 $\mathrm{CO}_{2}$ 의 유동 양상, 공극압력 변화 및 역학적 변형을 함께 고려한 지오메카닉스 모델 해석과 의 통합적 해석을 통한 분석이 필요하다고 할 수 있다. 또한, 주입 $\mathrm{CO}_{2}$ 의 절대압력치에 따라서는 주입압을 고 려한 유효응력 해석과 같은 일방향 연계해석이 아닌 공 극구조 변형에 따른 유체유동 양상까지 고려한 양방향 연계해석을 실시해야 할 것으로 보인다.

한편, $\mathrm{Kim}$ et al.(2010)은 $\mathrm{CO}_{2} \mathrm{EOR}$ 프로젝트 과정 중 미소지진 모니터링 배열을 위한 기초연구 결과를 발 표한 바 있으며 균열 방향성 및 지류층 이방성을 고려 한 최적 센서 배열 및 센서 종류에 대한 연구도 추가적 으로 실시되어야 할 것으로 보인다.

\section{5. 요약 및 결론}

본 고에서는 온실가스 저감방안으로서의 $\mathrm{CO}_{2}$ 지하 암반층 저장과 원유 생산 증진을 동시에 달성할 수 있 을 것으로 기대되는 $\mathrm{CO}_{2} \mathrm{EOR}$ 기술을 살펴보고, $\mathrm{CCS}$ 와 연계한 $\mathrm{CO}_{2}-\mathrm{EOR}$ 프로젝트의 대표 사례로서 캐나다 Weyburn 프로젝트 사례를 소개하였다.

$\mathrm{CO}_{2} \mathrm{EOR}$ 기술은 원유 회수 증진 목적으로 주입되는 대규모 $\mathrm{CO}_{2}$ 공급원 확보 측면에서 $\mathrm{CCS}$ 와의 연계가 유 용할 것으로 보이며 또한 원유 회수율 증진에 따른 신 규 부가가치 창출로 $\mathrm{CCS}$ 의 일련과정, 특히 포집분야에 추가적인 경제성을 부여할 수 있을 것으로 기대된다. 또한, 기존 유전지역을 대상으로 $\mathrm{CCS}$ 를 실시하기 때문 에 신규 CCS용 부지 선정에 비해 상대적으로 주민 수 용성 및 인허가 절차를 간소화할 수 있는 장점도 있다.

$\mathrm{CCS}$ 와 연계한 $\mathrm{CO}_{2} \mathrm{EOR}$ 기술 개발 및 확보를 위해 서는 $\mathrm{CO}_{2}$ 의 포집, 수송, 주입에 필요한 제반 기술 요소 와 함께 $\mathrm{CO}_{2} \mathrm{EOR}$ 의 효율 향상을 위한 기술요소들이 추가적으로 개발되어 통합되어야 한다. 이들 기술 요소 로는 코어 수공법(core flooding) 실내 실험을 통한 $\mathrm{CO}_{2}$ 의 혼화 및 비혼화 주입 기술, 최적 회수율 확보를 위한 MMP(Minimum Miscibility Pressure) 측정 기술, 유종별 $\mathrm{CO}_{2}$ 팽윤현상에 의한 PVT(Pressure-Volume-Temperature) 물성 및 점도강하 평가 기술, 현장 유전조건을 고려한 $\mathrm{CO}_{2}$ 저장능력 평가 및 주입증진 기술, $\mathrm{WAG}($ Water Alternating Gas) 및 수공법(water flooding) 기술을 이 용한 $\mathrm{CO}_{2}$ 주입 증진 기술, $\mathrm{CO}_{2}$ /원유 분리공정을 포함한 지상설비 기술, 고압의 $\mathrm{CO}_{2}$ 주입을 위한 압축 및 회수 재활용 시스템, $\mathrm{CO}_{2}$ 운영 현장설비 기술, 생산정 부식방 지를 위한 유정완결 시스템 설계기술 등을 들 수 있다. $\mathrm{CO}_{2} \mathrm{EOR}$ 기술은 대상 유전의 지질학적 특성, $\mathrm{CO}_{2}$ 의
품질 및 공급원 주변 인프라 조건에 따라 시설 설계는 물론 경제성 등이 달라지기 때문에 현장 연구를 통해 기술 및 경제적 위험성을 줄이는 방안이 도출되어야 함 이 지적된 바 있다(이근상 외, 2012). 국내의 경우, CCS 와 연계한 $\mathrm{CO}_{2} \mathrm{EOR}$ 요소 기술들은 개별적으로 확보할 수 있을 것으로 예상되나 주입을 위한 유전(특히, 육상 의 경우)의 확보가 사실상 불가능하므로 인도네시아 등 과 같은 석유기술 개발도상국의 유전 현장을 적극적으 로 활용하여 개발 기술의 검증 및 운영 노하우의 축적 이 이루어져야 할 것으로 보인다.

$\mathrm{CO}_{2} \mathrm{EOR}$ 프로젝트의 성공적인 수행을 위한 암반공 학적 쟁점으로는 장기적 관점에서 $\mathrm{CCS}$ 의 역할 수행이 가능하도록 $\mathrm{CO}_{2}$ 주입중 및 주입후의 지속적인 $\mathrm{AE} / \mathrm{MS}$ 모니터링을 통해 고압 유체 주입에 의한 균열 생성/진전 여부 및 누출 가능성의 지속적인 감시를 통한 안정성 평 가를 들 수 있다. 또한, $\mathrm{CO}_{2} \mathrm{EOR}$ 프로젝트의 안정적이 고 경제적인 운영을 위한 MMP와 MIP(Maximum Injection Pressure) 등의 적정주입압력을 사전 설계하고 장기운 영과정 중 시뮬레이션을 통한 누출 가능성을 예측할 필 요가 있다. 이를 위해서는 기존의 지하 심부를 대상으 로 한 열-수리-역학적 연계거동 해석기법에 원유/ $\mathrm{CO}_{2} /$ 지하수 등 저류층 내 유체 유동 및 PVT 거동을 고려한 지오메카닉스 해석모듈을 추가 개발하고 주입과정에서 의 지표면 융기량, 미소지진 발생 양상 등의 계측결과 와 비교/분석/수정과정을 반복함으로써 대상지역의 지 오메카닉스 모델을 업그레이드하고, 누출 시나리오 해 석 및 대응방안, 원유 회수율 증진 효과의 사전 예측 정 밀도를 향상 시킬 수 있을 것으로 기대된다.

\section{감사의 글}

본 연구는 2012년도 지식경제부의 재원으로 한국에 너지기술평가원(KETEP)의 지원을 받아 수행한 'EOR Screening을 통한 $\mathrm{CCS}$ 와 $\mathrm{CO}_{2}$-EOR 연계기술개발' 과 제(No. 2012T100201728)로 수행되었습니다. 또한, 본 고의 완성도 향상에 유익한 조언을 주신 익명의 심사위 원분들께 감사드립니다.

\section{참고문헌}

1. Kim, M., Byun, J., Seol, S., 2010, Study on microseismic monitoring method for enhanced oil recovery (EOR), Journal of the Korean Society for Geosystem Engineering, Vol. 47, No. 6, pp.871-879.

2. Kim, H.M., Park, E.S., Synn, J.H., Park, Y,C., 2008, Greenhouse gas (CO2) geological sequestration and 
geomechanical technology, Tunnel and Underground Space, Vol. 18, No. 3, pp.175-184.

3. 박의섭, 김현우, 천대성, 최헌수, $2012, \mathrm{CO}_{2}$ 지중저장의 암 반공학적 해결과제, 2012 한국자원공학회 추계학술발표회 CCS 특별세션, pp. 84-96.

4. Lee, K.S., Kim, J.W., Kim, H.T., Son, H.A., 2012, Potential opportunities and outlook of $\mathrm{CO} 2$ enhanced oil recovery associated with CCS, Journal of the Korean Society for Geosystem Engineering, Vol. 49, No. 5, pp.700-707.

5. Advanced Resources International Inc., 2009, IEA Greenhouse Gas R\&D Programme, $\mathrm{CO}_{2}$ storage in depleted oilfields: Global application criteria for carbon dioxide enhanced oil recovery, Report IEA/CON/08/155.

6. Andrei, M., Simoni, M., Delbianco, A., Cazzani, P., 2010, Enhanced Oil Recovery with $\mathrm{CO}_{2}$ Capture and Sequestration, World Energy Concil

7. Connolly, P.T., Cosgrove, J.W., 1999, Prediction of fracture induced permeability and fluid flow in the crust using experimental stress data, Bull. AAPG 85, pp. 757-777.

8. Deepak, T. 2009, Design of Non-Fluorous $\mathrm{CO}_{2}$ Soluble Compounds, Doctoral Dissertation, University of Pittsburgh.

9. Elsharkawy, A.M., Suez Canal, U., Poettmann, F.H., Christiansen, R.L., 1992, Measuring minimum miscibility pressure: slim-Tube or Rising-Bubble Method?, SPE/DOE Enhanced Oil Recovery Symposium, 22-24 April 1992, Tulsa, Oklahoma.

10. Godec, M.L., 2011, Global Technology Roadmap for $\mathrm{CCS}$ in Industry Sectoral Assessment $\mathrm{CO}_{2}$ Enhanced Oil
Recovery.

11. Hovorka, S.D., Tinker, S.W., 2010, EOR as sequestration: Geoscience perspective, The Symposium on the role of enhanced oil recovery in accelerating the deployment of carbon capture and storage, Cambridge, MA, July, 2010, GCCC Digital Publication Series \#10-12.

12. Mourits, F., 2008, Overview of IEA GHG WeyburnMidale $\mathrm{CO}_{2}$ Monitoring and Storage Project, $3^{\text {rd }}$ CSLF Workshop on Capacity Building for Carbon Capture and Storage (CCS), Al-Khobar, Saudi Arabia

13. NETL, 2010, Carbon Dioxide Enhanced Oil Recovery, National Energy Technology Laboratory.

14. Onuma, T., Ohkawa, S., 2009, Detection of surface deformation related with $\mathrm{CO}_{2}$ injection by DInSAR at In Salah, Algeria, Energy Procedia, Vol. 1, pp. 2177-2184.

15. Rutqvist, J., 2012, The geomechanics of $\mathrm{CO}_{2}$ stroage in deep sedimentary formations, Geotechnical and Geological Engineering 30, pp. 525-551.

16. SBI, 2010, EOR Enhanced Oil Recovery Worldwide, SBI Energy.

17. Verdon, J.P., 2010, Microseismic monitoring and geomechanical modelling of $\mathrm{CO}_{2}$ storage in subsurface reservoirs, Ph.D Dissertation, University of Bristol, U.K.

18. Verdon, J.P., Kendall, J.M., White, D.J., Angus, D.A., 2011, Linking microseismic event observations with geomechanical models to minimise the risks of storing $\mathrm{CO}_{2}$ in geological formations, Earth and Planetary Science Letters, Vol. 305, pp. 143-152.

\section{김 형 목}

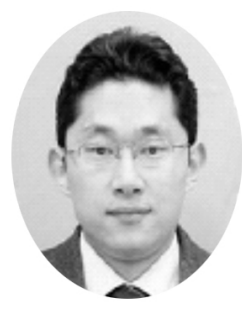

1997년 서울대학교 공과대학 자원공학 과 공학사

1999년 서울대학교 대학원 자원공학과 공학석사

2002년 동경대학교 대학원 토목공학과 공학박사

Tel: 02-3408-4387

E-mail: hmkim@sejong.ac.kr 현재 세종대학교 공과대학 에너지자원 공학과 부교수

\section{배 위 섭}

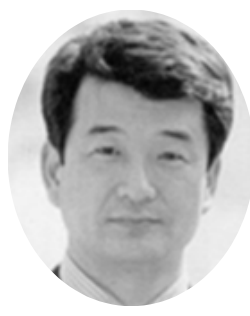
1983년 서울대학교 공과대학 자원공학 과 공학사

1987년 University of Texas at Austin 공학석사

1992년 University of Texas at Austin 공학박사

Tel: 02-3408-3969

E-mail: wsbae@sejong.ac.kr 현재 세종대학교 공과대학 에너지자원 공학과 교수 